\title{
PENGARUH KEPEMILIKAN INSTITUSIONAL DAN \\ INDIVIDUAL TERHADAP RISIKO EKSPROPRIASI PADA PERUSAHAN YANG TERDAFTAR DI BURSA EFEK INDONESIA
}

\author{
Muh. Abdi Imam \\ IAIN Palopo \\ Muh_abdi_imam@iainpalopo.ac.id
}

\begin{abstract}
,
tujuan penelitian ini adalah untuk menguji secara empiris pengaruh kepemilikan institusional dan kepemilikan individual terhadap risiko ekspropriasi pada perusahaan yang terdaftar di bursa efek indonesia priode 2010-2014.Penelitian ini dilakukan dengan mengunduh ringkasan laporan keuangan perusahaan non keuangan. Sampel terpilih sebanyak 71 perusahaan non keuangan yang terdaftar di BEI periode 2010-2014. Data dianalisis dengan regresi linear berganda menggunakan SPSS 21. Hasil penelitian menunjukkan kepemilikan institusional berpengaruh negatif terhadap risiko ekspropriasi dan kepemilikan individual berpengaruh positif terhadap resiko ekspropriasi
\end{abstract}

Keywords: institutional ownership, individual ownership and expropriation risk

\section{PENDAHULUAN / INTRODUCTION}

Ekspropriasi (perampasan) merupakan tindakan yang dilakukan oleh pihak pemegang saham pengendali (mayoritas) terhadap pemegang saham non pengendali (minoritas). Sugeng (2008), menyatakan bahwa pemegang saham pengendali ini disebut juga sebagai pemegang saham mayoritas atas kepemilikan perusahaan. La Porta et al (2007), dan Faccio et al (2009) menyatakan bahwa Semakin tinggi konsentrasi kepemilikan pada pihak tertentu akan memunculkan pihak pemegang saham mayoritas yang memiliki hak kontrol lebih terhadap perusahaan.

Jensen \& Meckling (1976), La Porta et al (1998), Claessens et al (2008), dan Sari (2010), menyatakan kepemilikan institusional dan kepemilikan individual dapat menyebabkan resiko ekspropriasi pada perusahaan. Masalah ekspropriasi merupakan masalah yang timbul sebagai akibat pihak-pihak yang terlibat dalam perusahaan mempunyai kepentingan yang berbedabeda. Yang disebabkan perbedaan jumlah saham yang di miliki pada perusahaan.

Penelitian yang dilakukan Cheung et al (2007), dan Chen (2007), menumukan bahwa kepemilikan institusional berpengaruh negatif terhadap risiko ekspropriasi. Sedangkan penelitian Lemmon \& Lins (2008), menemukan bahwa kepemilikan institusional tidak berpengaruh singnifikan terhadap risiko ekspropriasi. Adapun penelitian yang dilakukan Scott 
(2009), dan Sari (2010), menemukan bahwa kepemilikan individu berpengaruh positif terhadap risiko ekpropriasi.

Penelitian terkait kepemilikan instutisional dan kepemilikan individual telah banyak dilakukan di Indonesia seperti Sujoko \& Soebiantoro (2007), dan Hadiprajitno (2013), menemukan bahwa kepemilikan instutisional, kepemilikan individual, leverage, faktor intern, dan faktor ekstern berpengaruh positif terhadap nilai perusahaan. Namun pengujian pengaruh kepemilikan saham dikaitkan dengan risiko ekspropriasi, risiko agency theory tipe 2, belum banyak dilakukan.

Berdasarkan beberapa penelitian tentang risiko ekspropriasi yang telah dilakukan, tidak terdapat konsistensi terhadap hasil-hasil penelitian tersebut. Maka penelitian ini dilakukan dengan tujuan untuk mengetahui pengaruh struktur kepemilikan terhadap risiko ekspropriasi pada perusahaan non keuangan yang terdaftar di BEI periode 2010-2014.

\section{METODE PENELITIAN / METHODS}

\section{Lokasi dan Desain Penelitian}

Penelitian ini difokuskan pada perusahaan non keuangan yang tercatat di Bursa Efek Indonesia. Penelitian di desain untuk menguji hipotesis (hypothesis testing) yang menjelaskan pengaruh variabel independen terhadap dependen sehingga jenis penelitian ini adalah uji hipotesis. Hipotesis penelitian dikembangkan berdasarkan teori-teori yang berkaitan dengan topik penelitian dan selanjutnya diuji berdasarkan teknik analisis yang sesuai. Penelitian ini bersifat kausal yang bertujuan untuk mengukur kuat hubungan dan pengaruh antarvariabel dalam penelitian. Sebelum mengukur kuat hubungan dan pengaruh antara variabel independen dan variabel dependen, setiap variabel didefinisikan dan diukur berdasarkan proksinya.

\section{Motode Pengumpulan Data}

Jenis data yang digunakan dalam penelitian ini adalah data objek, sedangkan sumber data yang digunakan adalah data sekunder yang diperoleh peneliti secara tidak langsung dari BEI yang meliputi Indonesia Capital Market Directory (ICMD) dan laporan keuangan yang diterbitkan oleh BEI pada website www.idx.co.id. Metode pengumpulan data menggunakan metode dokumentasi. Metode dokumentasi adalah metode yang berdasarkan pada data sekunder yang dilakukan dengan cara mengumpulkan laporan keuangan perusahaan yang telah dipublikasikan oleh BEI.

\section{Model Analisis}


Untuk mengetahui risiko ekspropriasi pada perusahaan non keuangan yang terdaftar di BEI periode 2010-2014, maka digunakan regresi linear berganda dengan model analisis sebagai berikut :

$\operatorname{Expro}_{(S, P, A, L)}=\alpha_{0}+\beta_{1} \mathrm{KIns}+\beta_{2} \mathrm{KKel}+\varepsilon$

Keterangan:

Y : Ekspropriasi (Expro- $S, P, A, L)$

a : konstanta

$b_{1}$ dan $b_{2}:$ koefisien arah regresi

$\mathrm{x}_{1} \quad$ : Kepemilikan Institusional (KIns)

$\mathrm{x}_{3} \quad$ : Kepemilikan Individu/Keluarga (KKel)

e : Error.

\section{HASIL DAN PEMBAHASAN / DISCUSSION}

Hasil estimasi penelitian dilakukan untuk menguji hipotesis, kepemilikan institusional berpengaruh negatif terhadap risiko ekspropriasi pada perusahaan non keuangan yang terdaftar di Bursa Efek Indonesia (H1), dan kepemilikan individu berpengaruh positif terhadap risiko ekspropriasi pada perusahaan non keuangan yang terdaftar di Bursa Efek Indonesia (H2).

Berdasarkan hasil pengolahan data SPSS (Lampiran Tabel 1), maka dapat diketahui bahwa koefisien determinasi yang ditunjukkan oleh $A d j . R^{2}$ dari persamaan regresi menghasilkan nilai sebesar 0,561. Nilai tersebut dapat dijelaskan bahwa $56.1 \%$ dari variabel independen yang terdiri dari kepemilikan institusional, dan kepemilikan individu mampu menjelaskan variabel risiko ekspropriasi. Sisanya $43.9 \%$ yang dijelaskan oleh variabel lain di luar model. Hal ini mengartikan bahwa masih ada faktor-faktor lain yang sangat berpengaruh terhadap variabel resiko ekspropriasi. Pada uji signifikansi simultan yang ditunjukkan oleh Fstatistic, nilai yang dihasilkan oleh persamaan regresi sebesar 26,603 dengan signifikansi di bawah $\alpha=0.05$. Hal itu dapat dijelaskan bahwa kepemilikan institusional, dan kepemilikan individu secara simultan berpengaruh terhadap variabel ekspropriasi. Nilai konstan 1,891 menunjukkan bahwa apabila tidak terdapat variabel kepemilikan institusional, dan kepemilikan individu maka risiko ekspropriasi akan menurun hingga sebesar 1,891.

Koefisien regresi variabel kepemilikan institusional sebesar -0.018 menyatakan bahwa jika kepemilikan institusional meningkat sebesar 1\%, risiko ekspropriasi akan menurun sebesar -0.018. Pada tingkat signifikansi, kepemilikan institusional memiliki signifikansi sebesar 0.017 yang berada di bawah $\alpha=0.05$. Koefisien regresi variabel kepemilikan individu sebesar 
0.036 menyatakan bahwa jika kepemilikan individu meningkat sebesar $1 \%$, risiko ekspropriasi akan meningkat sebesar 0.036. Pada tingkat signifikansi, kepemilikan individu memiliki signifikansi sebesar 0.000 yang berada di bawah $\alpha=0.05$.

Penelitian ini menemukan bahwa kepemilikan institusional dan kepemilikan individu berpengaruh terhadap risiko ekspropriasi. Hal ini mengindikasikan bahwa risiko ekspropriasi yang di lakukan oleh pemegang saham pengendali terhadap pemegang saham non pengendali ditentukan oleh besarnya kepemilikan saham.

Hipotesis pertama dalam penelitian ini yaitu terdapat pengaruh negatif antara kepemilikan institusional terhadap risiko ekspropriasi pada perusahaan non keuangan yang terdaftar di Bursa Efek Indonesia. Hasil Uji hipotesis menunjukkan bahwa koefisien regresi (beta) adalah sebesar -0,018 yang menunjukkan arah negatif dengan nilai $t_{\text {hitung }}$ sebesar $-2,461$ dengan nilai signifikansi sebesar 0,017 lebih kecil dari nilai signifikansi yang ditetapkan $(0,017$ $<0,05)$. Oleh karena itu, kepemilikan institusional mempunyai pengaruh negatif dan signifikan terhadap risiko ekspropriasi. Sehingga dapat disimpulkan bahwa hipotesis yang pertama dapat diterima.

Pada variabel ini tanda negatif pada koefisien regresi menunjukkan bahwa apabila kepemilikan institusional meningkat maka risiko ekspropriasi akan menurun. Hasil ini menjelaskan bahwa proporsi kepemilikan institusional yang tinggi dapat berdampak pada penurunan risiko ekspropriasi karena adanya monitoring dari pihak institusional. Monitoring yang ketat atas kegiatan perusahaan dapat mengurangi tingkat risiko serta dapat meningkatkan pembiayaan (modal) dari investor, ini memicu pencapaian peningkatan laba perusahaan.

Laba diperlukan perusahaan agar dapat memertahankan kelangsungan hidupnya. Laba ini akan diperoleh jika perusahaan mampu memasarkan atau menjual barang-barang yang dihasilkan atau barang-barang yang ditawarkan, artinya perusahaan mempunyai keunggulan kompetitif. Untuk mencapai pada tujuan tersebut salah satu cara yang efektif dengan jalan memuaskan konsumen serta pemegang saham pada tingkat laba tertentu tanpa melupakan tanggung jawab sosialnya, sesuai konsep pemasaran. Dengan kondisi yang demikian itu perusahaan akan mampu memberikan informasi laporan keuangan yang berdaya guna sebagai alat bantu pengambilan keputusan dan akan memperkecil kemungkinan terjadinya ekspropriasi dalam perusahaan.

Hasil penelitian ini konsisten dengan penelitian sebelumnya yang dilakukan oleh Chen (2007), meneliti tentang hubungan antara kepemilikan institusional dan kinerja perusahaan- 
perusahaan non-keuangan Selandia Baru. Hasil penelitianya menunjukkan bahwa kepemilikan institusional berpengaruh negatif terhadap resiko ekspropriasi. Nielsen (2007), melakukan penelitian tentang apakah kepemilikan institusi keuangan dapat mengurangi risiko ekspropriasi antara pemegang saham dan manajer. Hasil penelitian Nielsen (2007), menunjukkan bahwa kepemilikan saham mayoritas oleh institusi keuangan dapat menekan risiko ekspropriasi karena istitusi keuangan dapat memonitoring kinerja manajemen sebagai pengelolah perusahaan. Hasil penelitian kali ini bertolak belakang dengan penelitian sebelumnya. Lemmon \& Lins (2008), yang melakukan penelitian tentang kepemilikan institusi keuangan terhadap terjadinya risiko ekspropriasi pemengang saham minoritas. Hasil penelitianya menunjukan bahwa kepemilikan institusional tidak berpengaruh signifikan terhadap risiko ekspropriasi

Hipotesis kedua dalam penelitian ini yaitu terdapat pengaruh positif antara kepemilikan individu terhadap risiko ekspropriasi pada perusahaan non keuangan yang terdaftar di Bursa Efek Indonesia. Hasil Uji hipotesis menunjukkan bahwa koefisien regresi (beta) adalah sebesar 0,036 yang menunjukkan arah negatif dengan nilai thitung sebesar 5,540 dengan nilai signifikansi sebesar 0,000 lebih kecil dari nilai signifikansi yang ditetapkan $(0,000<0,05)$. Oleh karena itu, kepemilikan institusional mempunyai pengaruh positif dan signifikan terhadap risiko ekspropriasi.

La Porta et al (2007), meneliti tentang pemegang saham individu terhadap perushaanperusahaa di Amerika Serikat khususnya di negara dengan perlindungan pemengang saham yang buruk. Hasil penelitiannya menunjukan bahwa kepemilikan individu berpengaruh positif terhadap resiko ekspropriasi. Claessens et al (2008), meneliti tentang adanya resiko ekspropriasi pada pemengang saham minoritas oleh pemengan saham individu pada 2.658 perusahan di Sembilan negara Asia Timur. Hasil penelitiannya menunjukkan bahwa kepemilikan individu berpengaruh positif terhadap risiko ekspropriasi. Sari (2010), meneliti tentang kepemilikan individu yang menpengaruhi transaksi-transaksi dengan pihak yang memiliki hubungan istimewa. Hasil penelitianya menunjukan bahwa kepemilikan individu berpengaruh positif terhadap transaksi-transaksi yang memungkinkan terjadinya risiko ekpropriasi. 
Hal ini dipengaruhi oleh adanya kepemilikan individu yang terkonsentrasi pada satu individu tertentu sehingga muncul hak kontrol terpusat pada individu. Kondisi seperti ini, memiliki peluang besar terjadinya ekspropriasi terhadap pemegang saham lainnya yang dilakukan oleh pemegang saham individu. Semakin tinggi persentase kepemilikan individu maka semakin tinggi peluang dilakukannya transaksi-transaksi ekspropriasi. Pada kepemilikan individu, pemegang saham individu yang menjadi pemilik perusahaan memiliki hak kontrol atas perusahaan akan mengambil keputusan untuk pencapaian tujuan perusahaan yaitu perolehan laba meningkat selama periode berjalan.

\section{KESIMPULAN / CONCLUSION}

Hasil penelitian ini menyimpulkan bahwa kepemilikan institusional mempunyai pengaruh negatif terhadap risiko ekspropriasi yang menandakan bahwa hipotesis 1 diterima. Dan kepemilikan individu berpengaruh positif terhadap risiko ekspropriasi yang menandakan bahwa hipotesis 2 diterima. Adapun saran dalam penelitian ini yang berdasarkan pada keterbatasan penelitian adalah bahwa sebaiknya peneliti-peneliti selanjutnya menambahkan variabel independen seperti proporsi kepemilikan manajemen dan kepemilikan pemerintah. Struktur kepemilikan yang digunakan dalam penelitian selanjutnya sebaiknya tidak hanya menggunakan kepemilikan imediat yang dapat langsung ditelusuri dalam laporan keuangan, namun menambahkan kepemilikan ultimat yang perlu dilakukan penelusuran kepemilikan secara mendetail dalam laporan keuangan yang dipublikasikan sehingga validitas proporsi kepemilikan kuat.

\section{DAFTAR PUSTAKA / REFERENCES}

Chen C.R., \& Mande V. (2008). Managerial Ownership and Firm Valuatin: Evidence from Japanese firms. Pacific-Basin Finance Journal, 1(2): 267-283.

Chen J. (2007). Does Institutional Ownership Create Values? The New Zealand Case. Department of Economics and Finance Massey University, New Zealand. Journal of Finance and Accounting, 47(4).

Chen S.Y., \& Ho K.W. (2009). Corporate Diversification, Ownership Structure, and Firm Value; The Singapore Evidence. Journal of Finance, 55(1).

Cheung Y., Rau P.R., \& Stouraitis A. (2007). Tunneling, Propping and Expropriation: Evidence from Connected Party Transaction In Hongkong. Journal of Financial Economics, 82(2): 343-386.

Claessens S., Djankov S., Fan J.P.H., \& Lang L.H.P. (2008). Expropriation of Minority Shareholders: Evidence from East Asia. Journal of Financial Economics, 58(1): 81112.

Faccio M., Lang L.H.P., \& Young L. (2009). Dividends and Expropriation. Journal of Financial Economics, 65(3): 365-395.

Hadiprajitno P.B. (2013). Stuktur Kepemilikan, Mekanisme Tata Kelola Perusahaan, dan Biaya Keagenan di Indonesia (Studi Empirik pada Perusahaan di Bursa Efek Indonesia). Jurnal Akuntansi dan Auditing, 9(2).

Jensen M.C., \& Meckling W.H. (1976). Theory of The Firm: Managerial Behavior, Agency Costs. and Ownership Structure. Journal of Financial Economics, 3(4): 305-360.

La Porta R., Silanes F.L.d., Shleifer A., \& Vishny R.W. (1998). Law and Finance. Journal of Political Economy, 106(1): 1113-1155. 
La Porta R., Silanes F.L.d., \& Shleifer A. (2007). Corporate Ownership Around the World. Journal of Finance 54(20): 471-517.

Lemmon M.L., \& Lins K.V. (2008). Ownership Structure, Corporate Governance, and Firm Value: Evidence from the East Asian Financial Crisis. Journal of Finance. 58(4): $1445-1468$.

Sari R.C. (2010). Tunneling dan Model Prediksi: Bukti Empiris pada Transaksi Pihak Berelasi. Disertasi. Program Doktor Universitas Gadjah Mada.

Scott W.R. (2009). Large Shareholders and Corporate Control. Journal of Political Economy, 94(3): 461-488.

Sugeng B. (2008). Pengujian Monitoring Rationale of Dividend dari Easterbrook di Lingkungan Perusahaan yang Listing di BEI. Jurnal Ekonomi Bisnis 9(5).

Sujoko \& Soebiantoro. (2007). Pengaruh Struktur Kepemilikan Saham, Leverage, Faktor

Intern dan Faktor Ekstern Terhadap Nilai Perusahaan. Jurnal Manajemen dan Kewirausahaan, $9(1): 47$ 